\title{
Time-resolved gas-phase kinetic and quantum chemical studies of the reaction of silylene with oxygen
}

Article

Published Version

Becerra, R., Bowes, S.J., Ogden, J.S., Cannady, J.P., Adamovic, I., Gordon, M.S., Almond, M.J. and Walsh, R. (2005) Time-resolved gas-phase kinetic and quantum chemical studies of the reaction of silylene with oxygen. Physical Chemistry Chemical Physics, 7 (15). pp. 2900-2908. ISSN 1463-9076 doi: https://doi.org/10.1039/b504760a Available at https://centaur.reading.ac.uk/11004/

It is advisable to refer to the publisher's version if you intend to cite from the work. See Guidance on citing.

To link to this article DOI: http://dx.doi.org/10.1039/b504760a

Publisher: Royal Society of Chemistry

All outputs in CentAUR are protected by Intellectual Property Rights law, including copyright law. Copyright and IPR is retained by the creators or other copyright holders. Terms and conditions for use of this material are defined in the End User Agreement. 


\section{CentAUR}

Central Archive at the University of Reading

Reading's research outputs online 


\title{
Time-resolved gas-phase kinetic and quantum chemical studies of the reaction of silylene with oxygen
}

\author{
Rosa Becerra, ${ }^{a}$ Sarah-Jane Bowes, ${ }^{b}$ J. Steven Ogden, ${ }^{b}$ J. Pat Cannady, ${ }^{c}$ Ivana Adamovic, ${ }^{d}$ \\ Mark. S Gordon, ${ }^{d}$ Matthew J. Almond ${ }^{e}$ and Robin Walsh*e \\ a Instituto de Quimica-Fisica 'Rocasolano', C.S.I.C., C/Serrano 119, 28006 Madrid, Spain \\ ${ }^{b}$ School of Chemistry, University of Southampton, Highfield, Southampton, UK SO17 1 BJ \\ ${ }^{c}$ Dow Corning Corporation, Mail Stop CO1232, 2200 West Salzburg Road, P.O. Box 994, \\ Midland, MI 48686-0994, USA \\ ${ }^{d}$ Department of Chemistry, Iowa State University, Ames, IA 50011, USA \\ ${ }^{e}$ School of Chemistry, University of Reading, Whiteknights, P.O. Box 224, Reading, \\ UK RG6 6AD. E-mail: r.walsh@reading.ac.uk
}

Received 6th April 2005, Accepted 9th June 2005

First published as an Advance Article on the web 24th June 2005

Time-resolved kinetic studies of the reaction of silylene, $\mathrm{SiH}_{2}$, generated by laser flash photolysis of phenylsilane, have been carried out to obtain rate constants for its bimolecular reaction with $\mathrm{O}_{2}$. The reaction was studied in the gas phase over the pressure range 1-100 Torr in $\mathrm{SF}_{6}$ bath gas, at five temperatures in the range 297-600 K. The second order rate constants at 10 Torr were fitted to the Arrhenius equation:

$$
\log \left(k / \mathrm{cm}^{3} \text { molecule } \mathrm{s}^{-1} \mathrm{~s}^{-1}\right)=(-11.08 \pm 0.04)+\left(1.57 \pm 0.32 \mathrm{~kJ} \mathrm{~mol}^{-1}\right) / R T \ln 10
$$

The decrease in rate constant values with increasing temperature, although systematic is very small. The rate constants showed slight increases in value with pressure at each temperature, but this was scarcely beyond experimental uncertainty. From estimates of Lennard-Jones collision rates, this reaction is occurring at $c a$. 1 in 20 collisions, almost independent of pressure and temperature. Ab initio calculations at the G3 level backed further by multi-configurational (MC) SCF calculations, augmented by second order perturbation theory (MRMP2), support a mechanism in which the initial adduct, $\mathrm{H}_{2} \mathrm{SiOO}$, formed in the triplet state $(\mathrm{T})$, undergoes intersystem crossing to the more stable singlet state (S) prior to further low energy isomerisation processes leading, via a sequence of steps, ultimately to dissociation products of which the lowest energy pair are $\mathrm{H}_{2} \mathrm{O}+\mathrm{SiO}$. The decomposition of the intermediate cyclo-siladioxirane, via $\mathrm{O}-\mathrm{O}$ bond fission, plays an important role in the overall process. The bottleneck for the overall process appears to be the $\mathrm{T} \rightarrow \mathrm{S}$ process in $\mathrm{H}_{2} \mathrm{SiOO}$. This process has a small spin-orbit coupling matrix element, consistent with an estimate of its rate constant of $1 \times 10^{9} \mathrm{~s}^{-1}$ obtained with the aid of RRKM theory. This interpretation preserves the idea that, as in its reactions in general, $\mathrm{SiH}_{2}$ initially reacts at the encounter rate with $\mathrm{O}_{2}$. The low values for the secondary reaction barriers on the potential energy surface account for the lack of an observed pressure dependence. Some comparisons are drawn with the reactions of $\mathrm{CH}_{2}+\mathrm{O}_{2}$ and $\mathrm{SiCl}_{2}+\mathrm{O}_{2}$.

\section{Introduction}

Silylenes are of importance because they are implicated in the thermal and photochemical breakdown mechanisms of silicon hydrides and organosilanes, as well as being key intermediates in CVD. Time resolved kinetic studies, carried out in recent years, have shown that the simplest silylene, $\mathrm{SiH}_{2}$, reacts rapidly and efficiently with many chemical species. ${ }^{1,2}$ Examples of its reactions include $\mathrm{Si}-\mathrm{H}$ bond insertions, $\mathrm{C}=\mathrm{C}$ and $\mathrm{C} \equiv \mathrm{C}$ $\pi$-bond additions. ${ }^{3} \mathrm{SiH}_{2}$ also reacts with many small inorganic molecules such as $\mathrm{CO},{ }^{4} \mathrm{CO}_{2},{ }^{5} \mathrm{~N}_{2} \mathrm{O},{ }^{6} \mathrm{H}_{2} \mathrm{O}\left(\mathrm{D}_{2} \mathrm{O}\right),{ }^{7-9} \mathrm{HCl}^{10}$ and NO. ${ }^{11}$ This class of reactions exhibit significant rate variations, including temperature and pressure dependences, which can be accounted for by a common mechanism involving initial formation of a donor acceptor complex whose behaviour, either continuing rearrangement, or redissociation back to reactants, determines the overall rate. The kinetic findings in all cases are supported by quantum chemical (ab initio) calculations. ${ }^{4-11}$ The reactant molecules in these cases are either all closed shell, or in the case of NO have one unpaired electron. We turn our attention here to the reaction of $\mathrm{SiH}_{2}$ with $\mathrm{O}_{2}$ (reaction (1)), an example of a reaction of silylene with a triplet state molecule. Quite apart from comparisons of reactivity of $\mathrm{SiH}_{2}$ with small molecules, the reaction of $\mathrm{SiH}_{2}+\mathrm{O}_{2}$ has importance in the mechanism of silicon hydride oxidation processes and is a key reaction in $\mathrm{SiH}_{4}-\mathrm{O}_{2}$ explosions. ${ }^{12}$

There have been two direct rate studies of this reaction. The first was carried out by $\mathrm{Chu}$, Beach, Estes and Jasinski ${ }^{13}$ (CBEJ), using laser resonant absorption flash kinetic spectroscopy (LRAFKS). CBEJ measured rate constants of $(7.5 \pm$ $0.8) \times 10^{-12} \mathrm{~cm}^{3}$ molecule $\mathrm{s}^{-1}$ at 1 Torr and $(1.4 \pm 0.2) \times$ $10^{-11} \mathrm{~cm}^{3}$ molecule $\mathrm{s}^{-1}$ at 9.5 Torr using helium buffer gas at room temperature. The second and more recent was carried out by Guo, Fikri, Friedrichs and Temps ${ }^{14}$ (GFFT) using cavity ring down spectroscopy (CRDS). GFFT measured a rate constant of $(1.64 \pm 0.32) \times 10^{-11} \mathrm{~cm}^{3}$ molecule $\mathrm{s}^{-1} \mathrm{~s}^{-1}$ independent of pressure (Ar buffer gas) between 1.9 and 260 Torr, also at room temperature.

The analogous reaction of methylene, $\mathrm{CH}_{2}$, is of importance in combustion chemistry. ${ }^{15} \mathrm{~A}$ further interest to us was to compare the behaviour towards $\mathrm{O}_{2}$ of $\mathrm{SiH}_{2}$ and $\mathrm{SiCl}_{2}$, which we have studied by end product analysis. ${ }^{16}$ The reaction of $\mathrm{SiH}_{2}$ with $\mathrm{O}_{2}$ is likely, initially, to form an acyclic adduct in the triplet state, ${ }^{17}$ viz.

$$
\mathrm{SiH}_{2}+\mathrm{O}_{2} \rightarrow{ }^{3} \mathrm{H}_{2} \mathrm{SiOO}
$$


Theoretical calculations ${ }^{17 b}$ have shown that, on the singlet surface, acyclic $\mathrm{H}_{2} \mathrm{SiOO}$ undergoes facile ring closure to the more stable cyclo- $\mathrm{H}_{2} \mathrm{Si}(\mathrm{O})_{2}$. A homologue of the latter, dimethyldioxasilirane, has been prepared by the reaction of $\mathrm{SiMe}_{2}+\mathrm{O}_{2}$ in an Ar matrix at $10 \mathrm{~K} .{ }^{18}$ No studies of the product of the $\mathrm{SiH}_{2}+\mathrm{O}_{2}$ reaction have been carried out, but it is believed that formation of $\mathrm{SiO}+\mathrm{H}_{2} \mathrm{O}$ is an important channel. ${ }^{19}$ There have been a number of theoretical calculations of the enthalpies of formation of potential intermediates in this reaction system and of parts of the reaction energy surface. ${ }^{17,20-23}$ We report here both gas-phase kinetic studies (over a wide range of temperatures and pressures) and quantum chemical calculations of the energy surface.

\section{Experimental}

\section{Equipment, chemicals and method}

The apparatus and equipment for these studies have been described in detail previously. ${ }^{24,25}$ Only essential and brief details are therefore included here. $\mathrm{SiH}_{2}$ was produced by the $193 \mathrm{~nm}$ flash photolysis of phenylsilane $\left(\mathrm{PhSiH}_{3}\right)$ using a Coherent Compex 100 exciplex laser. Photolysis pulses were fired into a variable temperature quartz reaction vessel with demountable windows, at right angles to its main axis. $\mathrm{SiH}_{2}$ concentrations were monitored in real time by means of a Coherent 699-21 single-mode dye laser pumped by an Innova 90-5 argon ion laser and operating with Rhodamine 6G. The monitoring laser beam was multipassed 36 times along the vessel axis, through the reaction zone, to give an effective path length of $1.5 \mathrm{~m}$. A portion of the monitoring beam was split off before entering the vessel for reference purposes. The monitoring laser was tuned to $17259.50 \mathrm{~cm}^{-1}$, corresponding to a known strong vibration-rotation transition ${ }^{26}$ in the $\mathrm{SiH}_{2}$ $\mathrm{A}\left({ }^{1} \mathrm{~B}_{1}\right) \leftarrow \mathrm{X}\left({ }^{1} \mathrm{~A}_{1}\right)$ absorption band. Light signals were measured by a dual photodiode/differential amplifier combination and signal decays were stored in a transient recorder (Datalab DL910) interfaced to a BBC microcomputer. This was used to average the decays of between 5 and 20 photolysis laser shots (at a repetition rate of 0.5 or $1 \mathrm{~Hz}$ ). The averaged decay traces were processed by fitting the data to an exponential form using a non-linear least squares package. This analysis provided the values for first-order rate coefficients, $k_{\text {obs }}$, for removal of $\mathrm{SiH}_{2}$ in the presence of known partial pressures of substrate gas.

Gas mixtures for photolysis were made up, containing between 3.0 and $9.0 \mathrm{mT}$ Torr of $\mathrm{PhSiH}_{3}, 0-2.0$ Torr of $\mathrm{O}_{2}$ and inert diluent $\left(\mathrm{SF}_{6}\right)$ up to total pressures of between 1 and 100 Torr. Pressures were measured by capacitance manometers (MKS, Baratron). All gases used in this work were frozen and rigorously pumped to remove any residual air prior to use. $\mathrm{PhSiH}_{3}(99.9 \%)$ was obtained from Ventron-Alfa (Petrarch). $\mathrm{O}_{2}(99.6 \%)$ was from BOC. Sulfur hexafluoride, $\mathrm{SF}_{6}$, (no GCdetectable impurities) was from Cambrian Gases.

\section{Ab initio calculations}

Most of the electronic structure calculations reported here were performed with the Gaussian 98 software package. ${ }^{27}$ Structures were determined by energy minimization at the MP2 = Full/6$31 \mathrm{G}(\mathrm{d})$ level. Transition State structures were characterised as first order saddle points by calculation of the Hessian matrix. Stable structures, corresponding to energy minima, were identified by possessing no negative eigenvalues of the Hessian, whilst transition states were identified by having one and only one negative eigenvalue. The standard Gaussian-3 (G3) compound method ${ }^{28}$ was employed to determine final energies for all local minima. For transition states the elements of the G3 method were used, viz. optimization to TS at $\mathrm{HF} / 6-31 \mathrm{G}(\mathrm{d})$, frequencies at $\mathrm{HF} / 6-31 \mathrm{G}(\mathrm{d})$, optimization to TS at MP2 = Full/ 6-31G(d), followed by four single point energy determinations at the MP2 = Full/6-31G(d) geometry, viz. QCISD(T)/6-
31G(d), MP4/6-31 + G(d), MP4/6-31G(2df,p), and MP2 = full/ G3large, and the values were combined according to the G3 procedure. ${ }^{28}$ The identities of the transition state structures were verified by calculation of Intrinsic Reaction Co-ordina$\operatorname{tes}^{29 a}$ (IRC) at the MP2 $=$ Full/6-31G(d) or B3LYP/6-31G(d) levels. Reaction barriers were calculated as differences in G3 enthalpies at $298.15 \mathrm{~K}$. Where required harmonic frequencies were obtained from the values calculated at the $\mathrm{HF} / 6-31 \mathrm{G}(\mathrm{d})$ level adjusted by the correction factor 0.893 appropriate to this level. $^{30}$

For part of the energy surface of these studies, where a single configurational wave-function was inadequate, further calculations were carried out with the GAMESS ${ }^{31}$ electronic structure code. Geometry optimizations were performed using multiconfigurational self-consistent field (MCSCF) wavefunctions, ${ }^{32}$ within the Fully Optimized Reaction Space (FORS) ${ }^{33,34}$ model with the $6-31 \mathrm{G}(\mathrm{d})$ basis set. ${ }^{35}$ Energy corrections at $\mathrm{MCSCF} / 6-$ $31 \mathrm{G}(\mathrm{d})$ geometries were taken into account using multi-reference second order perturbation theory ${ }^{36,37}$ (MRMP2). For energy corrections the cc-pVTZ ${ }^{38}$ basis set was employed. Stationary points were confirmed as in the G3 calculations. IRC calculations, linking transition states to reactants and products, were carried out using the Gonzalez-Schlegel second order integration method, ${ }^{29 b}$ with a step size of 0.05 $\left((\mathrm{amu})^{1 / 2}\right.$ - bohr). The spin-orbit coupling (SOC) matrix elements were obtained using the full Breit-Pauli ${ }^{39}$ Hamiltonian.

\section{Results}

\section{Kinetics}

Preliminary experiments established that, for a given reaction mixture, decomposition decay constants, $k_{\text {obs }}$, were not dependent on the exciplex laser energy $\left(50-70 \mathrm{~mJ}\right.$ pulse $^{-1}$, routine variation) or number of photolysis laser shots (up to 20 shots). The constancy of $k_{\text {obs }}$ ( 5 shot averages) showed no effective depletion of reactants. Higher pressures of precursor were required at the higher temperatures because signal intensities decreased with increasing temperature. However, for the purposes of rate constant measurement at a given temperature the $\mathrm{PhSiH}_{3}$ pressure was kept fixed. At each temperature of study, a series of experiments was carried out to investigate the dependence of $k_{\text {obs }}$ on $\mathrm{O}_{2}$ pressure (at least six different values). The results of these experiments are shown in Fig. 1, where good linear fits were obtained, as expected for second order kinetics. The second order rate constants derived from the gradients of these plots by least squares fitting, are shown in Table 1 . The error limits are single standard deviations and are fairly small. While it is apparent that the rate constants decrease with increasing temperature (as has been found in

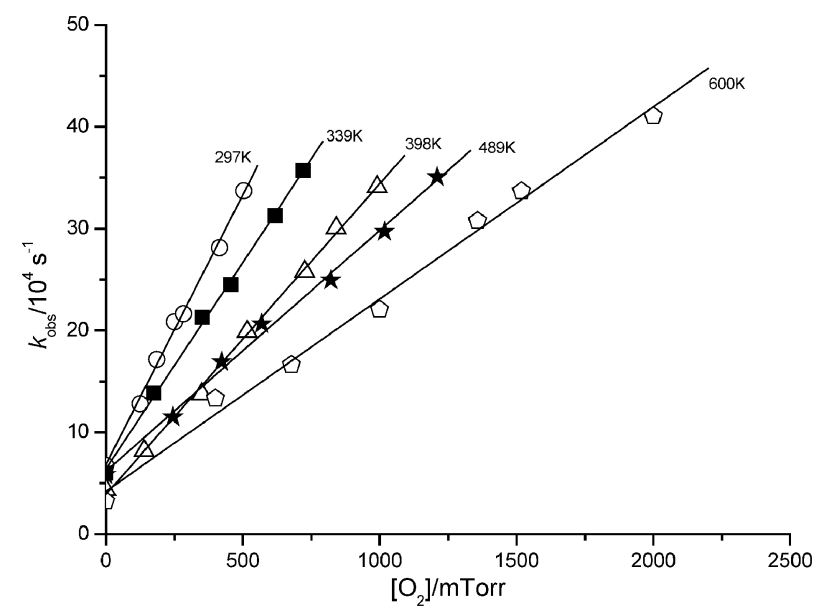

Fig. 1 Second order plots for reaction of $\mathrm{SiH}_{2}+\mathrm{O}_{2}$ at $10 \mathrm{Torr}\left(\mathrm{SF}_{6}\right)$ at different temperatures (indicated). 
Table 1 Experimental second-order rate constants for $\mathrm{SiH}_{2}+\mathrm{O}_{2}$ at several temperatures $\left(\left[\mathrm{SF}_{6}\right]=10\right.$ Torr $)$

\begin{tabular}{ll}
\hline$T / \mathrm{K}$ & $k / 10^{-11} \mathrm{~cm}^{3}$ molecule $^{-1} \mathrm{~s}^{-1}$ \\
\hline 297 & $1.64 \pm 0.03$ \\
339 & $1.43 \pm 0.02$ \\
398 & $1.25 \pm 0.02$ \\
489 & $1.20 \pm 0.03$ \\
600 & $1.19 \pm 0.04$ \\
\hline
\end{tabular}

other similar $\mathrm{SiH}_{2}$ reactions ${ }^{1,2,4,6,8-11,25}$ ), the extent of the decrease is not much beyond the experimental uncertainties in the rate constants.

In addition to these experiments, some runs were carried out with the total pressure (mainly $\mathrm{SF}_{6}$ ) varied in the range 1-100 Torr at each temperature. The results of these runs are shown in Table 2. Error limits are higher at pressures other than 10 Torr because less experimental points were involved in obtaining these fits. The results show a slight increase in the rate constant values between 1 and 100 Torr. However this is, for the most part, scarcely beyond $20 \%$ and does not vary systematically with temperature. We have not displayed it in a figure because it would be too congested. Given that the uncertainties in rate constant values are $c a . \pm 10 \%$ the variation is hardly beyond reasonable experimental scatter. Thus, we have no strong reason to believe that the rate constants measured at 10 Torr should represent anything other than the values for the true bimolecular process. These values have been fitted to the Arrhenius equation, a plot of which is shown in Fig. 2. Although the plot shows some curvature, the deviations from linearity correspond to less than $5 \%$ uncertainty in the rate constants. Thus, the fit is reasonably good and the resulting equation is:

$$
\begin{aligned}
& \log \left(k / \mathrm{cm}^{3} \text { molecule }{ }^{-1} \mathrm{~s}^{-1}\right)=(-11.08 \pm 0.04) \\
& +\left(1.57 \pm 0.32 \mathrm{~kJ} \mathrm{~mol}^{-1}\right) / R T \ln 10
\end{aligned}
$$

In order to try to relate these results to the mechanism of the reaction we have investigated the underlying potential energy surface, calculations of which are described in the next section.

\section{Quantum chemical (ab initio) calculations}

Possible species on the $\mathrm{SiH}_{2} \mathrm{O}_{2}$ potential energy surface (PES) were explored in detail at the G3 level of theory. Apart from the reactant species $\mathrm{SiH}_{2}+\mathrm{O}_{2}$, eight isomeric five-atomic molecules (stable minima) were found as well as six pairs of dissociation fragments. In addition eleven transition states were identified, not including those for dissociation processes. Apart from these, calculations at the higher MCSCF and MRMP2 levels identified a further species (the $\mathrm{H}_{2} \mathrm{Si}\left(\mathrm{O}^{\circ}\right)_{2}$ diradical) and the transition states leading to and from it. The stable species and the transition states linking them are shown in the potential energy surface in Fig. 3 and their structures in Figs. $4 \mathrm{a}$ and $4 \mathrm{~b}$. Total energies and relative enthalpy values are listed in Table 3. Some less stable conformers of some of the species shown and listed were also

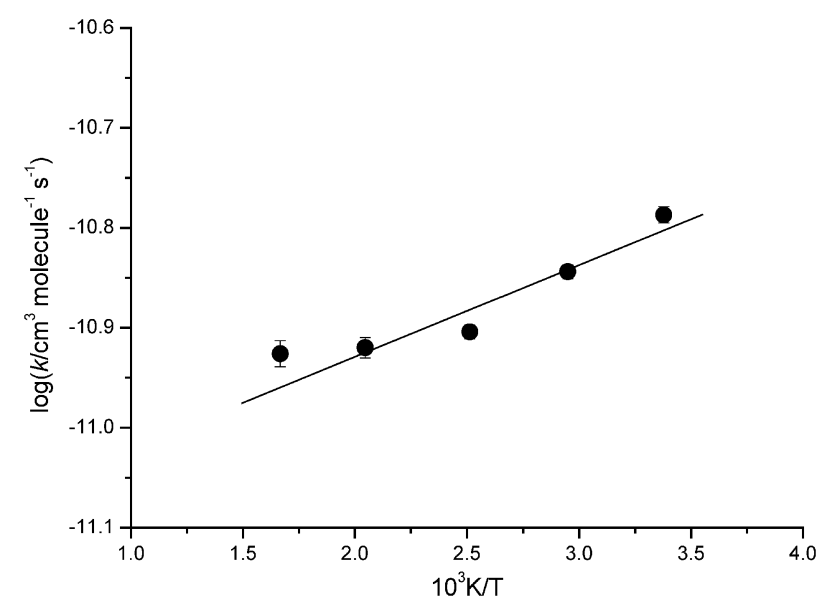

Fig. 2 Arrhenius plot of second-order rate constants for $\mathrm{SiH}_{2}+\mathrm{O}_{2}$ at $10 \operatorname{Torr}\left(\mathrm{SF}_{6}\right)$.

found, but because they do not affect the conclusions of this paper they are not included.

When $\mathrm{SiH}_{2}$ and $\mathrm{O}_{2}$ initially combine they naturally form the silyleneperoxy species in the triplet $(\mathrm{T})$ state, by spin conservation. This species is the silicon analogue of the Criegee intermediate of ozonolysis fame. ${ }^{40} \mathrm{We}$ find no energetic barrier for this process. It is assumed that this will react further, initially by spin inversion (intersystem crossing) to the singlet (S) silyleneperoxy species which lies lower in energy. This process is discussed in more detail later. Although not found in these calculations, transition states for formation of $\mathrm{H}_{2} \mathrm{SiOO}(\mathrm{T})$ and (S) are designated TS1a and TS1b for consistency with the reaction numbering system. From this point on it was assumed that all further important species would lie on the singlet surface. No further triplet state species were considered. $\mathrm{H}_{2} \mathrm{SiOO}(\mathrm{S})$ can react further by ring closure via a low energy transition state, TS2, to form cyclo- $\mathrm{H}_{2} \mathrm{SiO}_{2}\left(C_{2 \mathrm{v}}\right.$ point group), siladioxirane. From this point we find a bifurcation of the surface. The lowest energy pathway, identified only at the MCSCF and MRMP2 levels, occurs via $\mathrm{O}-\mathrm{O}$ rupture in siladioxirane to form the diradical species $\mathrm{H}_{2} \mathrm{Si}\left(\mathrm{O}^{\circ}\right)_{2}$ via a low energy transition state, TS3a. A 1,2 $\mathrm{H}$-shift process from $\mathrm{Si}$ to $\mathrm{O}$, via another low energy transition state, TS4a, then leads from the diradical to silanoic acid, $\mathrm{HSi}(=\mathrm{O}) \mathrm{OH}$, (the silicon analogue of formic acid). This pathway from cyclo- $\mathrm{H}_{2} \mathrm{SiO}_{2}$ to $\mathrm{HSi}(=\mathrm{O}) \mathrm{OH}$ is discussed in more detail below. There is an alternative, higher energy, route from siladioxirane to silanoic acid. This pathway starts via the transition state TS3b, involving a 1,2 $\mathrm{H}$-shift from $\mathrm{Si}$ to $\mathrm{O}$ without breaking the ring. The product, cyclo- $\mathrm{HSiOOH}$, may be thought of as an internally complexed form of hydroperoxysilylene. This ring can also open by $\mathrm{O}-\mathrm{O}$ bond cleavage, via $\mathrm{TS} 4 \mathrm{~b}$, to give $\mathrm{HSi}(=\mathrm{O}) \mathrm{OH}$. Both routes to silanoic acid involve substantial energy gains, deriving in part from formation of the $\mathrm{Si}=\mathrm{O}$ double bond. For silanoic acid the most favourable next step in this complex pathway involves a 1,2 $\mathrm{H}$-shift from $\mathrm{Si}$ to $\mathrm{O}$ via TS6a leading to dihydroxysilylene, $\mathrm{Si}(\mathrm{OH})_{2}$, the lowest energy species on the whole surface. The stability of this species derives from the fact

Table 2 Pressure dependence of second-order rate constants $\left(k / 10^{-11} \mathrm{~cm}^{3}\right.$ molecule $\left.{ }^{-1} \mathrm{~s}^{-1}\right)$ for $\mathrm{SiH}_{2}+\mathrm{O}_{2}$ in the temperature range $297-600 \mathrm{~K}$

\begin{tabular}{rlllll}
\hline & \multicolumn{1}{l}{$T / \mathrm{K}$} & & & \\
\cline { 2 - 6 }$P /$ Torr & 297 & 339 & 398 & 489 & 600 \\
\hline 1 & $1.48 \pm 0.15$ & $1.30 \pm 0.13$ & $1.00 \pm 0.10$ & $1.02 \pm 0.10$ & $1.11 \pm 0.11$ \\
3 & $1.62 \pm 0.16$ & $1.36 \pm 0.14$ & $1.16 \pm 0.12$ & $1.02 \pm 0.10$ & $1.23 \pm 0.12$ \\
10 & $1.64 \pm 0.03$ & $1.43 \pm 0.02$ & $1.25 \pm 0.02$ & $1.20 \pm 0.03$ & $1.19 \pm 0.04$ \\
30 & $1.62 \pm 0.16$ & $1.55 \pm 0.16$ & $1.33 \pm 0.13$ & $1.13 \pm 0.11$ & $1.27 \pm 0.13$ \\
100 & $1.68 \pm 0.17$ & $1.60 \pm 0.16$ & $1.43 \pm 0.14$ & $1.17 \pm 0.12$ & $1.34 \pm 0.13$ \\
\hline
\end{tabular}




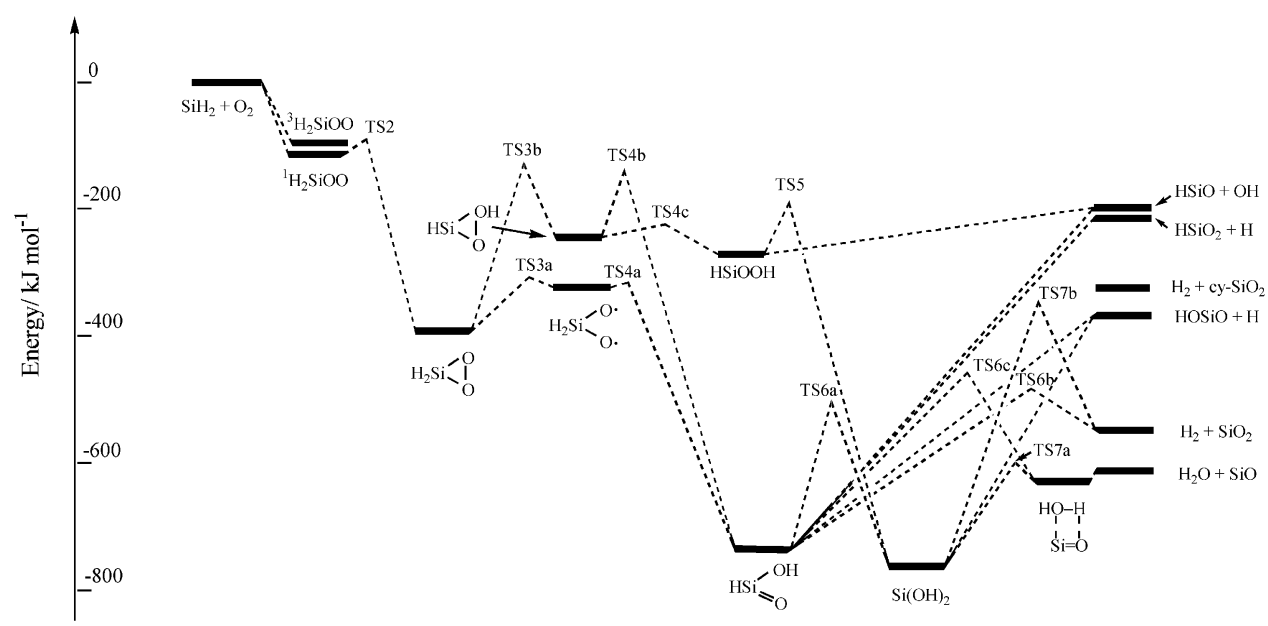

Fig. 3 Potential energy (enthalpy) surface showing the most likely molecular species involved in the reaction of $\mathrm{SiH}_{2}+\mathrm{O}_{2}$. Most enthalpies are calculated at the ab initio $(\mathrm{G} 3)$ level. TS3a, $\mathrm{H}_{2} \mathrm{Si}\left(\mathrm{O}^{\circ}\right)_{2}$ and TS4a calculated at MRMP2/MCSCF.

that not only is it a silylene, but it has the added $\mathrm{p}_{\pi}$ stabilisation provided by lone pair $\mathrm{O} \rightarrow \mathrm{Si}$ donation from the two $\mathrm{OH}$ groups. There is an alternative route to $\mathrm{Si}(\mathrm{OH})_{2}$. Cyclo$\mathrm{HSiOOH}$ can ring open to its more stable acyclic form, hydroperoxysilylene, $\mathrm{HSiOOH}$, by way of the low energy transition state TS4c. Then an unusual, so called dyotropic, ${ }^{41,42}$ pathway from $\mathrm{HSiOOH}$, involving synchronous migrations of $\mathrm{OH}$ (from $\mathrm{O}$ to $\mathrm{Si}$ ) and $\mathrm{H}$ (from $\mathrm{Si}$ to $\mathrm{O}$ ), leads directly to $\mathrm{Si}(\mathrm{OH})_{2}$, via TS5. Undoubtedly the driving force here is the big gain in energy of nearly $400 \mathrm{~kJ} \mathrm{~mol}^{-1}$ caused, in large part, by formation of a strong $\mathrm{Si}-\mathrm{O}$ bond at the expense of a weak $\mathrm{O}-\mathrm{O}$ bond. The probable final products in this reaction system can now all be envisaged as resulting from dissociation pathways from one or other of silanoic acid and dihydroxysilylene. The lowest energy product pair, $\mathrm{H}_{2} \mathrm{O}+\mathrm{SiO}$, is reached from $\mathrm{Si}(\mathrm{OH})_{2}$ by a four centre elimination of water via TS7a, passing via a weak $\pi$-complex en route. These products can also be reached from $\mathrm{HSi}(=\mathrm{O}) \mathrm{OH}$ by a 1,1 elimination of water via TS6c, passing via the same complex, although the barrier for this is much higher. The next lowest energy product pair is $\mathrm{H}_{2}+\mathrm{SiO}_{2}$, which can be reached from $\mathrm{HSi}(=\mathrm{O}) \mathrm{OH}$ by a 1,2 hydrogen elimination via TS6b. $\mathrm{H}_{2}+$ $\mathrm{SiO}_{2}$ can also be formed from $\mathrm{Si}(\mathrm{OH})_{2}$ via the 5 membered ring TS7b. This is a higher energy route making it less likely. There is a further pathway involving $\mathrm{H}_{2}$ elimination leading directly from cyclo- $\mathrm{H}_{2} \mathrm{SiO}_{2}$ via $\mathrm{TS} 3 \mathrm{c}$ to cyclo- $\mathrm{SiO}_{2}$, a high energy cyclic isomer of silicon dioxide. The energy of the $\mathrm{H}_{2}+$ cyclo-SiO product pair is shown in Fig. 3 but TS3c, although lying below the energy threshold, is omitted both because it is a less likely pathway and for purposes of diagram clarity. Despite the uphill nature of the fragmentation steps on this energy surface, there is such a large energy release in this system that not only (a)

$$
\text { (11) }
$$

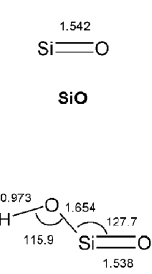

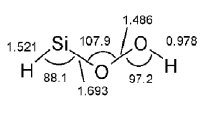

HoSiO
HSiOOH

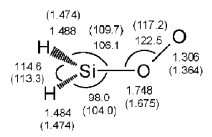

$\mathrm{H}_{2} \mathrm{SiOO}$ (S)

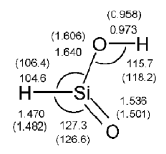

$\mathrm{HSi}(=0) \mathrm{OH}$

$$
\mathrm{O} \stackrel{1.531}{=} \mathrm{Si}=\mathrm{O}
$$

$\mathrm{SiO}_{2}$

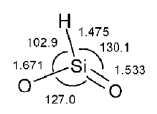

$\mathrm{HSiO}_{2}$
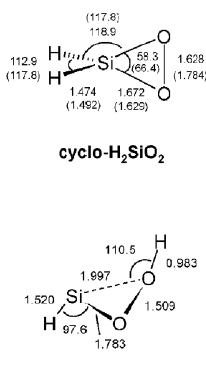

cyclo-HSiOOH

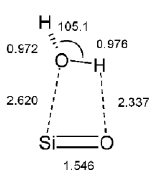

$\mathrm{SiO}-\mathrm{H}_{2} \mathrm{O}$ complex

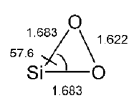

cyclo-SiO

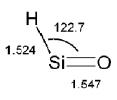

HSiO (b)

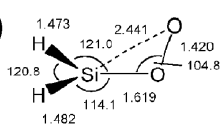

TS2

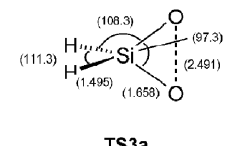

TS3a
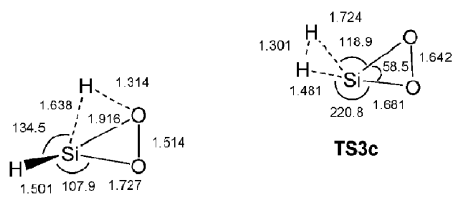

TS3b
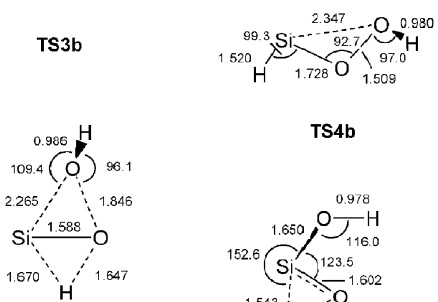

TS5

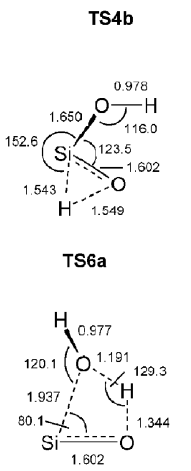

TS7a
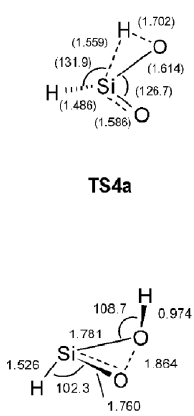

TS4a

TS4c

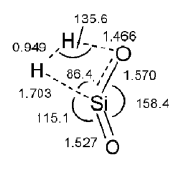

TS6b

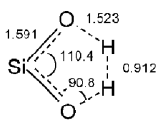

TS7b

Fig. 4 (a). Ab initio calculated geometries of local minimum structures involved in the $\mathrm{SiH}_{2}+\mathrm{O}_{2}$ reaction. Selected distances are given in $\AA$ and angles in ${ }^{\circ}$. Most values are for MP2 $=$ Full $/ 6-31 \mathrm{G}(\mathrm{d})$; figures in parentheses are at MCSCF(FORS) $/ 6-31 \mathrm{G}(\mathrm{d})$. (b). Ab initio calculated geometries of transition states involved in the $\mathrm{SiH}_{2}+\mathrm{O}_{2}$ reaction. Selected distances are given in $\AA$ and angles in ${ }^{\circ}$. Most values are for MP2 $=\mathrm{Full} / 6-31 \mathrm{G}(\mathrm{d})$; figures in parentheses are at MCSCF(FORS)/6-31G(d). 
Table 3 Ab initio (G3) Enthalpies for $\mathrm{SiH}_{2} \mathrm{O}_{2}$ species involved in the reaction of $\mathrm{SiH}_{2}$ with $\mathrm{O}_{2}$

\begin{tabular}{|c|c|c|}
\hline Molecular species & Energy/hartree & Relative energy $/ \mathrm{kJ} \mathrm{mol}^{-1}$ \\
\hline $\mathrm{SiH}_{2}+\mathrm{O}_{2}$ & -440.698609 & 0 \\
\hline $\mathrm{H}_{2} \mathrm{SiOO}(\mathrm{T})$ & -440.739384 & -107 \\
\hline $\mathrm{H}_{2} \mathrm{SiOO}(\mathrm{S})$ & -440.744714 & -121 \\
\hline TS2 & -440.737299 & -102 \\
\hline Cyclo- $\mathrm{H}_{2} \mathrm{SiO}_{2}$ & -440.847361 & -391 \\
\hline TS3a & $a$ & $a$ \\
\hline $\mathrm{H}_{2} \mathrm{Si}\left(\mathrm{O}^{\bullet}\right)_{2}$ & $a$ & $a$ \\
\hline TS4a & $a$ & $a$ \\
\hline $\mathrm{HSi}(=\mathrm{O}) \mathrm{OH}$ & -440.979361 & -737 \\
\hline TS3b & -440.749330 & -133 \\
\hline Cyclo-HSiOOH & -440.791441 & -244 \\
\hline TS4b & -440.759720 & -160 \\
\hline TS6a & -440.897088 & -521 \\
\hline $\mathrm{Si}(\mathrm{OH})_{2}$ & -440.991228 & -768 \\
\hline TS4c & -440.788620 & -236 \\
\hline $\mathrm{HSiOOH}$ & -440.801403 & -270 \\
\hline TS5 & -440.773016 & -195 \\
\hline TS7a & -440.927667 & -601 \\
\hline $\mathrm{SiO} \cdots \mathrm{H}_{2} \mathrm{O}^{\bullet}$ complex & -440.939194 & -632 \\
\hline $\mathrm{H}_{2} \mathrm{O}+\mathrm{SiO}$ & -440.930631 & -609 \\
\hline TS6c & -440.879946 & -452 \\
\hline TS6b & -440.881573 & -480 \\
\hline TS7b & -440.835312 & -359 \\
\hline $\mathrm{H}_{2}+\mathrm{SiO}_{2}$ & -440.908915 & -552 \\
\hline $\mathrm{HOSiO}+\mathrm{H}$ & -440.837728 & -365 \\
\hline $\mathrm{HSiO}_{2}+\mathrm{H}$ & -440.781938 & -219 \\
\hline $\mathrm{HSiO}+\mathrm{OH}$ & -440.776613 & -205 \\
\hline TS3c & -440.717948 & -51 \\
\hline $\mathrm{H}_{2}+$ cyclo- $\mathrm{SiO}_{2}$ & -440.819600 & -318 \\
\hline
\end{tabular}

are all the pathways to molecular products available but also a number of product pairs involving $\mathrm{H}$ atoms or $\mathrm{OH}$ radicals. $\mathrm{HOSiO}+\mathrm{H}$ can be formed from both $\mathrm{Si}(\mathrm{OH})_{2}$ and $\mathrm{HSi}(=\mathrm{O})$ $\mathrm{OH}$. $\mathrm{HSiO}_{2}+\mathrm{H}$ can be formed from $\mathrm{HSi}(=\mathrm{O}) \mathrm{OH}$. Finally $\mathrm{HSiO}+\mathrm{OH}$ can be formed from $\mathrm{HSi}(=\mathrm{O}) \mathrm{OH}$ and also $\mathrm{HSiOOH}$. Since these products are all free radical pairs, we assumed that the dissociations leading to them involved no extra barriers.

A previous $s^{2}{ }^{23}$ of the part of the PES that connects cyclo- $\mathrm{H}_{2} \mathrm{SiO}_{2}$ to $\mathrm{HSi}(=\mathrm{O}) \mathrm{OH}$, suggested that the use of a multiconfigurational wave function is necessary, due to a large number of singlet and triplet surfaces that are close to each other in energy. We therefore undertook MCSCF calculations using an active space consisting of 6 electrons distributed in 6 orbitals, denoted $\operatorname{MCSCF}(6,6)$, as suggested by Murukami et al. ${ }^{23}$ The active orbitals were two $\sigma$ bonding and two $\sigma^{*}$ antibonding $\mathrm{Si}-\mathrm{H}$ orbitals, plus the $\sigma$ bonding and $\sigma^{*}$ antibonding $\mathrm{O}-\mathrm{O}$ orbitals. The natural orbital occupation numbers (NOON) for the two most active orbitals in the two transition states, designated TS3a and TS4a for consistency with the whole PES, are: TS3a $\left(\sigma(\mathrm{O}-\mathrm{O})=1.2455, \sigma^{*}(\mathrm{O}-\mathrm{O})=\right.$ $0.7546)$ and TS4a $\left(\sigma(\mathrm{Si}-\mathrm{H})=1.2474\right.$ and $\left.\sigma^{*}(\mathrm{Si}-\mathrm{H})=0.7526\right)$. For closed shell species, these NOON should be $(2.0,0.0)$, so both transition states have large singlet biradical character. This confirms that multiconfigurational methods (MCSCF and MRMP2) are important for a proper description of the behaviour of the system in these regions of configuration space.

Table 4 summarizes the energetics at both MCSCF and MRMP2 levels of theory, for both the 6-31G(d) and cc-pVTZ basis sets for this part of the pathway. Contrary to the earlier studies, ${ }^{23}$ it is predicted here that the transformation of cyclo$\mathrm{H}_{2} \mathrm{SiO}_{2}$ to $\mathrm{HSi}(=\mathrm{O}) \mathrm{OH}$ involves two distinct steps. The first step is a ring opening, followed by the $\mathrm{H}$ transfer in the second step. Breaking the $\mathrm{O}-\mathrm{O}$ bond in the first step of the transfor-
Table 4 Ab initio $(\operatorname{MCSCF}(6,6))$ energetics $\left(\mathrm{kJ} \mathrm{mol}^{-1}\right)$ of the pathway from cyclo- $\mathrm{H}_{2} \mathrm{SiO}_{2}$ to $\mathrm{HSi}(=\mathrm{O}) \mathrm{OH}$

\begin{tabular}{lcrrrr}
\hline \multirow{2}{*}{ Species } & \multicolumn{2}{c}{ Basis set: 6-31G(d) } & & \multicolumn{2}{c}{ Basis set: cc-pVTZ } \\
\cline { 2 - 3 } \cline { 5 - 6 } & MCSCF & MRMP2 & & MCSCF & MRMP2 \\
\hline${\text { Cyclo- }{ }_{2} \mathrm{SiO}_{2}}$ & 0.0 & 0.0 & & 0.0 & 0.0 \\
$\mathrm{TS} 3 \mathrm{a}$ & 9.6 & 60.2 & & 15.5 & 76.6 \\
$\mathrm{H}_{2} \mathrm{Si}\left(\mathrm{O}^{\bullet}\right)_{2}$ & -4.2 & 36.8 & & 4.2 & 58.2 \\
$\mathrm{TS} 4 \mathrm{a}$ & 112.5 & 42.7 & & 104.2 & 47.7 \\
$\mathrm{HSi}(=\mathrm{O}) \mathrm{OH}$ & -277.4 & -322.6 & & -289.5 & -356.9 \\
\hline
\end{tabular}

mation process, has an MRMP2/cc-pVTZ barrier of $\sim 76 \mathrm{~kJ}$ $\mathrm{mol}^{-1}$. The barrier of the $\mathrm{H}$ transfer step is much smaller. Indeed, with the larger basis set, MRMP2 at the MCSCF geometry, predicts that the local minimum, which we designate $\mathrm{H}_{2} \mathrm{Si}\left(\mathrm{O}^{\circ}\right)_{2}$, is higher in energy than TS4a. This implies either that the second transition state may not exist, or that the TS4a geometry at MRMP2 is shifted from the MCSCF structure. To explore this point further, a series of single point MRMP2/ccpVTZ calculations were performed along the MCSCF IRC path that connects $\mathrm{TS} 4 \mathrm{a}$ with $\mathrm{HSi}(=\mathrm{O}) \mathrm{OH}$ in one direction and $\mathrm{H}_{2} \mathrm{Si}\left(\mathrm{O}^{\circ}\right)_{2}$ in the other. This analysis indicates that there appears to be an MRMP2 TS4a that is located more towards $\mathrm{H}_{2} \mathrm{Si}\left(\mathrm{O}^{\bullet}\right)_{2}$, with a small barrier of $c a . \sim 20 \mathrm{~kJ} \mathrm{~mol}^{-1}$. Basis set effects were explored for this part of the system but are not very pronounced, the biggest change in going from $6-31 \mathrm{G}(\mathrm{d})$ to ccpVTZ is $\sim 20 \mathrm{~kJ} \mathrm{~mol}^{-1}$ for $\mathrm{H}_{2} \mathrm{Si}\left(\mathrm{O}^{\bullet}\right)_{2}$ (at MRMP2). Much more important are dynamic correlation effects, taken into account with MRMP2, since the inclusion of dynamic correlation changes barrier heights by up to $\sim 110 \mathrm{~kJ} \mathrm{~mol}^{-1}$ (e.g. second barrier MCSCF vs. MRMP2).

The overall transformation of cyclo- $\mathrm{H}_{2} \mathrm{SiO}_{2}$ to $\mathrm{HSi}(=\mathrm{O}) \mathrm{OH}$ is a highly exothermic process, with the energy difference between reactants and products $\sim 320 \mathrm{~kJ} \mathrm{~mol}^{-1}$ (MCSCF) and $\sim 360 \mathrm{~kJ} \mathrm{~mol}^{-1}$ (MRMP2). This compares with $340 \mathrm{~kJ}$ $\mathrm{mol}^{-1}$ calculated at G3. The energetics of this part of the surface have been incorporated into the PES of Fig. 3 (without the minor correction from $E$ to $H_{298}$ ).

\section{The mechanism and some further theoretical considerations}

The $a b$ initio derived PES of Fig. 3, with its series of low secondary reaction barriers, taken in conjunction with the lack of any serious pressure dependence of the observed rate constants, indicates that there is little obvious hindrance to reaction on this energy surface. However, prior to reaction on this (singlet) surface the reaction must undergo intersystem crossing from triplet silylene-oxygen adduct. We report here a brief investigation of the lifetime of $\mathrm{H}_{2} \mathrm{SiOO}(\mathrm{T})$ and also of its transition probability to $\mathrm{H}_{2} \mathrm{SiOO}(\mathrm{S})$. The mechanism under consideration is as follows:

$$
\mathrm{SiH}_{2}+\mathrm{O}_{2} \underset{-1 \mathrm{a}}{\stackrel{\text { a }}{\rightleftharpoons}} \mathrm{H}_{2} \mathrm{SiOO}(\mathrm{T}) \stackrel{1 \mathrm{~b}}{\longrightarrow} \mathrm{H}_{2} \mathrm{SiOO}(\mathrm{S})
$$

To establish the lifetime of $\mathrm{H}_{2} \mathrm{SiOO}(\mathrm{T})$ we undertook RRKM calculations of the rate constant for its redissociation to $\mathrm{SiH}_{2}+$ $\mathrm{O}_{2}, k_{-1 \mathrm{a}}$. The parameters required for this were estimated by the same procedure as used for $\mathrm{H}_{2} \mathrm{SiNO}^{11}$ and other $\mathrm{SiH}_{2}$ containing adducts, ${ }^{25,43-45}$ using the $\mathrm{G} 3$ ab initio calculations as the sources of molecular vibrational wavenumbers and $E_{\mathrm{o}}$, the critical energy for decomposition. The parameters employed are shown in Table 5. The results of these calculations are expressed in terms of the microcanonical rate constants, $k_{-1 \mathrm{a}}(E)$ as a function of energy for the initially formed vibrationally excited molecules, $\mathrm{H}_{2} \mathrm{SiOO}(\mathrm{T})^{*}$ and are shown in Table 6. Over the range of thermal population of 
Table 5 Molecular and transition state parameters for RRKM calculations for decomposition of the $\mathrm{H}_{2} \mathrm{SiOO}(\mathrm{T})^{a}$

\begin{tabular}{lll}
\hline Parameter & $\mathrm{H}_{2} \operatorname{SiOO}(\mathrm{T})$ & $\mathrm{TS}^{a}$ \\
\hline$\tilde{\nu} / \mathrm{cm}^{-1}$ & 2154 & 2154 \\
& 2134 & 2134 \\
& 1032 & 1480 \\
& 913 & 913 \\
& 780 & rxn coord \\
& 715 & 140 \\
& 667 & 130 \\
& 254 & 51 \\
$A / \mathrm{s}^{-1}$ & 158 & 31 \\
$E_{\mathrm{o}} / \mathrm{kJ} \mathrm{mol}^{-1}$ & & $4.46 \times 10^{15}$ \\
$Z / 10^{-10} \mathrm{~cm}^{3}$ molecule & 93.7 \\
${ }^{a} \mathrm{Calculated} \mathrm{at} 296 \mathrm{~K} .^{-1}$ & & 4.52 \\
\hline
\end{tabular}

$\mathrm{H}_{2} \mathrm{SiOO}(\mathrm{T})^{*}$ molecules, values are in the range $10^{10}-10^{12} \mathrm{~s}^{-1}$. Collision frequencies in the experimental pressure region are in the range $10^{7}-10^{9} \mathrm{~s}^{-1}$, which clearly indicates that collisional stabilisation will be very uncompetitive with redissociation for $\mathrm{H}_{2} \mathrm{SiOO}(\mathrm{T})^{*}$. If there were no other pathway for reaction for $\mathrm{H}_{2} \mathrm{SiOO}(\mathrm{T})^{*}$, this shows that the $\mathrm{SiH}_{2}+\mathrm{O}_{2}$ reaction would be a third body assisted association reaction near to its low pressure limit under experimental conditions. The virtual lack of pressure dependence shows that the removal process for $\mathrm{H}_{2} \mathrm{SiOO}(\mathrm{T})^{*}$, viz. intersystem crossing, must also be relatively fast. An estimate of the rate constant, $k_{1 \mathrm{~b}}$, for this process may be obtained as follows. For the scheme in eqn. (2), $k_{1}$ (obs) = $k_{1 \mathrm{a}}\left(\left\langle k_{1 \mathrm{~b}}\right\rangle /\left\langle k_{-1 \mathrm{a}}\right\rangle\right)$ where $\left\langle k_{1 \mathrm{~b}}\right\rangle$ and $\left\langle k_{-1 \mathrm{a}}\right\rangle$ are the average values for the rate constants for steps $1 \mathrm{~b}$ and $1 \mathrm{a}$ for the energized $\mathrm{H}_{2} \mathrm{SiOO}(\mathrm{T})^{*}$ molecules. If we take $k_{1}(\mathrm{obs})=1.64 \times 10^{-11} \mathrm{~cm}^{3}$ molecule $\mathrm{s}^{-1}$ and $k_{1 \mathrm{a}}=3.55 \times 10^{-10} \mathrm{~cm}^{3}$ molecule $\mathrm{s}^{-1} \mathrm{~s}^{-1}$ (see Discussion) then $\left(\left\langle k_{1 \mathrm{~b}}\right\rangle /\left\langle k_{-1 \mathrm{a}}\right\rangle\right)=0.046$. To obtain $\left\langle k_{-1 \mathrm{a}}\right\rangle$, $k_{-1 \mathrm{a}}(E)$ values were averaged over a population distribution, $g(E)$, assumed to be Boltzmann, viz.

$$
\left\langle k_{-1 a}\right\rangle=\sum_{E} g(E) k_{-1 a}(E) / \sum_{E} g(E)
$$

Details of these $E$-dependent functions are shown in Table 6 The evaluation using eqn. (3) leads to a value for $\left\langle k_{-1 \mathrm{a}}\right\rangle$ of $2.2 \times 10^{10} \mathrm{~s}^{-1}$. Therefore $\left\langle k_{1 \mathrm{~b}}\right\rangle=1.0 \times 10^{9} \mathrm{~s}^{-1}$. This value corresponds to the summation of all possible intersystem crossing pathways accessible to the vibrationally excited $\mathrm{H}_{2} \mathrm{SiOO}(\mathrm{T})$ species. The theoretical calculation of this rate constant is beyond the scope of this work, but to have an idea of the order of magnitude of the possible rate of intersystem crossing we have investigated the spin orbit coupling between $\mathrm{H}_{2} \mathrm{SiOO}(\mathrm{T})$ and $\mathrm{H}_{2} \mathrm{SiOO}(\mathrm{S})$, at a geometry which is an average of those for these species. For this calculation the $\mathrm{H}_{2} \mathrm{SiOO}$ (T) and (S) structures were optimized using $\operatorname{MCSCF}(4,4)$ and
$\operatorname{MCSCF}(8,8)$ active spaces. The $\operatorname{MCSCF}(8,8)$ active space consisted of two $\sigma$ and two $\sigma^{*} \mathrm{Si}-\mathrm{H}$ orbitals, one $\sigma$ and $\sigma^{*}$ $\mathrm{Si}-\mathrm{O}$ and one $\sigma$ and $\sigma^{*} \mathrm{O}-\mathrm{O}$ orbitals. The $\operatorname{MCSCF}(4,4)$ active space is a subset of the $\operatorname{MCSCF}(8,8)$ active space, with one $\sigma$ and $\sigma^{*} \mathrm{Si}-\mathrm{O}$ and one $\sigma$ and $\sigma^{*} \mathrm{O}-\mathrm{O}$ orbitals. The singlet state is lower in energy by $6.7 \mathrm{~kJ} \mathrm{~mol}^{-1}$ at the $\operatorname{MCSCF}(4,4)$ level of theory, while inclusion of dynamic correlation (MRMP2) increases this splitting to $25.1 \mathrm{~kJ} \mathrm{~mol}^{-1}$. The splitting using the $\operatorname{MCSCF}(8,8)$ active space is very similar: 7.1 and $26.4 \mathrm{~kJ}$ $\mathrm{mol}^{-1}$ for MCSCF and MRMP2, respectively. Since the splitting is the same for both active spaces, the SOC calculations were carried out with the smaller active space. For all three geometries, the SOC matrix element is very small, $<1 \mathrm{~cm}^{-1}$. Calculations of transition probabilities, using the LandauZener formula ${ }^{46}$ gives values in the range $1.2 \times 10^{-4}$ and $8.6 \times 10^{-3}$ for a range of transition velocities between 10 and $700 \mathrm{~m} \mathrm{~s}^{-1}$. The relationship between this and the $\mathrm{H}_{2} \mathrm{SiOO}(\mathrm{T})$ lifetime is discussed in the next section.

\section{Discussion}

\section{General comments and rate constant comparisons}

The main experimental purpose of this paper was to measure the rate constants and their temperature and pressure dependences for the reaction of $\mathrm{SiH}_{2}+\mathrm{O}_{2}$. This has been accomplished. The reaction is found to have a moderately high A factor and a small negative activation energy. This is discussed in more detail below. Comparison with previous studies at room temperature shows good consistency. $\mathrm{CBEJ}^{13}$ obtained values for the rate constant of $(7.5 \pm 0.8) \times 10^{-12} \mathrm{~cm}^{3}$ molecule $\mathrm{s}^{-1}$ at 1 Torr and $(1.4 \pm 0.2) \times 10^{-11} \mathrm{~cm}^{3}$ molecule $\mathrm{s}^{-1}$ at 9.5 Torr in He buffer gas (and an intermediate value at 5 Torr He), while GFFT ${ }^{14}$ obtained an average value of $(1.64 \pm 0.32) \times 10^{-11} \mathrm{~cm}^{3}$ molecule ${ }^{-1} \mathrm{~s}^{-1}$ independent of pressure (Ar buffer gas) between 1.9 and 260 Torr. Allowing for systematic error, our value of $(1.64 \pm 0.16) \times$ $10^{-11} \mathrm{~cm}^{3}$ molecule $\mathrm{s}^{-1}$ at 10 Torr ( $\mathrm{SF}_{6}$ buffer gas) is in excellent agreement with both studies. Our finding of a very slight pressure dependence is also in reasonable agreement with CBEJ, where at 1 Torr total pressure, use of $\mathrm{He}$, a weaker collider gas than $\mathrm{SF}_{6}$, is expected to show a greater effect (value drops by $46 \%$ in He compared with $10 \%$ in $\mathrm{SF}_{6}$ ). On the other hand, the overall increase in our rate constants between 1 and 100 Torr $\mathrm{SF}_{6}$ (Table 2 ) is only $14 \%$, well within the uncertainty spread of values of GFFT claiming no variation with pressure. An earlier study by one of us, based on relative rate measurements, gives a much lower value for the room temperature rate constant, ${ }^{47}$ which we cannot explain. However it has to be acknowledged that being less direct, relative rate studies are less reliable. Another comparison is with the reaction of $\mathrm{SiCl}_{2}+\mathrm{O}_{2}$ for which Sandu et al. ${ }^{48}$ obtained a rate constant of $(5.6 \pm 1.2) \times 10^{-12} \mathrm{~cm}^{3}$ molecule $\mathrm{s}^{-1} \mathrm{~s}^{-1}$ at $298 \mathrm{~K}$. Experiments were carried out in 100 Torr of argon and no pressure

Table 6 Microcanonical rate constants, relative populations and fluxes calculated for the reaction; $\mathrm{H}_{2} \mathrm{SiOO}(\mathrm{T}) \rightarrow \mathrm{SiH}_{2}+\mathrm{O}_{2}$ at $298 \mathrm{~K}$

\begin{tabular}{|c|c|c|c|c|c|}
\hline$E / \mathrm{cm}^{-1}$ & $E / \mathrm{kJ} \mathrm{mol}^{-1}$ & $k_{-1 \mathrm{a}}(E) / \mathrm{s}^{-1} a$ & $\left(E-E_{\mathrm{o}}\right) / \mathrm{cm}^{-1}$ & $g(E)^{b}$ & Flux $/ \mathrm{s}^{-1 c}$ \\
\hline 8000 & 95.7 & $2.67 \times 10^{9}$ & 165 & 0.448 & $1.20 \times 10^{9}$ \\
\hline 8200 & 98.1 & $1.70 \times 10^{10}$ & 365 & 0.170 & $2.89 \times 10^{9}$ \\
\hline 8400 & 100.5 & $5.38 \times 10^{10}$ & 565 & 0.0642 & $3.45 \times 10^{9}$ \\
\hline 8600 & 102.8 & $1.25 \times 10^{11}$ & 765 & 0.0243 & $3.03 \times 10^{9}$ \\
\hline 8800 & 105.3 & $2.39 \times 10^{11}$ & 965 & $9.18 \times 10^{-3}$ & $2.19 \times 10^{9}$ \\
\hline 9000 & 107.7 & $4.07 \times 10^{11}$ & 1165 & $3.47 \times 10^{-3}$ & $1.41 \times 10^{9}$ \\
\hline 9200 & 110.1 & $6.40 \times 10^{11}$ & 1365 & $1.31 \times 10^{-3}$ & $8.41 \times 10^{8}$ \\
\hline 9400 & 112.5 & $9.44 \times 10^{11}$ & 1565 & $4.97 \times 10^{-4}$ & $4.69 \times 10^{8}$ \\
\hline 9600 & 114.8 & $1.34 \times 10^{12}$ & 1765 & $1.88 \times 10^{-4}$ & $2.52 \times 10^{8}$ \\
\hline 9800 & 117.2 & $1.82 \times 10^{12}$ & 1965 & $7.11 \times 10^{-5}$ & $1.29 \times 10^{8}$ \\
\hline
\end{tabular}


Table 7 Comparison of Arrhenius parameters for selected $\mathrm{SiH}_{2}$ reactions $^{a}$

\begin{tabular}{|c|c|c|c|}
\hline Reaction & $\log \left(A / \mathrm{cm}^{3}\right.$ molecule $\left.{ }^{-1} \mathrm{~s}^{-1}\right)$ & $E_{\mathrm{a}} / \mathrm{kJ} \mathrm{mol}^{-1}$ & Ref. \\
\hline $\mathrm{SiH}_{2}+\mathrm{SiH}_{4}$ & $-9.91 \pm 0.04$ & $-2.1 \pm 0.2$ & 25 \\
\hline $\mathrm{SiH}_{2}+\mathrm{GeH}_{4}$ & $-9.88 \pm 0.02$ & $-3.3 \pm 0.3$ & 50 \\
\hline $\mathrm{SiH}_{2}+\mathrm{C}_{2} \mathrm{H}_{4}$ & $-9.97 \pm 0.03$ & $-2.9 \pm 0.2$ & 43 \\
\hline $\mathrm{SiH}_{2}+\mathrm{C}_{2} \mathrm{H}_{2}$ & $-9.99 \pm 0.03$ & $-3.3 \pm 0.2$ & 44 \\
\hline $\mathrm{SiH}_{2}+\mathrm{NO}$ & $-9.97 \pm 0.18$ & $-3.4 \pm 1.3$ & 11 \\
\hline $\mathrm{SiH}_{2}+\mathrm{Me}_{2} \mathrm{CO}$ & $-10.17 \pm 0.04$ & $-4.5 \pm 0.3$ & 45 \\
\hline $\mathrm{SiH}_{2}+\mathrm{N}_{2} \mathrm{O}$ & $-12.09 \pm 0.04$ & $-2.0 \pm 0.3$ & 6 \\
\hline $\mathrm{SiH}_{2}+\mathrm{CO}_{2}$ & $-11.89 \pm 0.13$ & $16.4 \pm 1.2$ & 5 \\
\hline $\mathrm{SiH}_{2}+\mathrm{HCl}$ & $-11.51 \pm 0.06$ & $-1.9 \pm 0.5$ & 10 \\
\hline $\mathrm{SiH}_{2}+\mathrm{O}_{2}$ & $-11.08 \pm 0.04$ & $-1.6 \pm 0.3$ & This work \\
\hline
\end{tabular}

${ }^{a}$ High pressure limiting values (for pressure dependent reactions).

dependence was reported. The threefold slower reaction for $\mathrm{SiCl}_{2}$ compared with $\mathrm{SiH}_{2}$ is consistent with the general reduced reactivity of $\mathrm{SiCl}_{2}$ compared with $\mathrm{SiH}_{2}{ }^{49}$

To try to put this study into the perspective of the range of kinetic behaviour exhibited by $\mathrm{SiH}_{2}$, a comparison of Arrhenius parameters for its reactions with a variety of different substrate molecules is shown in Table 7. The clear distinction can be drawn between the high $A$ factor processes $\left(\log \left(A / \mathrm{cm}^{3}\right.\right.$ molecule $\mathrm{s}^{-1}$ ) in the range -9.8 to -10.2$)$ of $\mathrm{SiH}_{4}, \mathrm{GeH}_{4}$, $\mathrm{C}_{2} \mathrm{H}_{4}, \mathrm{C}_{2} \mathrm{H}_{2}, \mathrm{NO}$ and $\mathrm{Me}_{2} \mathrm{CO}$ and the low $A$ factor processes $\left(\log \left(A / \mathrm{cm}^{3}\right.\right.$ molecule $\left.{ }^{-1} \mathrm{~s}^{-1}\right)$ in the range -11.1 to -12.1$)$ of $\mathrm{N}_{2} \mathrm{O}, \mathrm{CO}_{2}, \mathrm{HCl}$ and $\mathrm{O}_{2}$. Another comparison can be made in terms of collision efficiency. We have calculated the LennardJones collision numbers, $Z_{\mathrm{LJ}}$, of $\mathrm{SiH}_{2}$ with the molecules of all these reactions at $298 \mathrm{~K}$, and used them to work out collision efficiencies. The results, shown in Table 8 , indicate the same two groupings of reactant molecules as in Table 7, with the high $A$ factor group having collision efficiencies close to $100 \%$ whereas the low $A$ factor group have much lower efficiencies. $\mathrm{CO}_{2}$ is exceptionally low because it also has (unusually for $\mathrm{SiH}_{2}$ reactions) a positive activation energy. These divisions do not depend on the reaction type. The efficient group includes bond insertion processes $\left(\mathrm{SiH}_{4}, \mathrm{GeH}_{4}\right), \pi$-type additions $\left(\mathrm{C}_{2} \mathrm{H}_{4}, \mathrm{C}_{2} \mathrm{H}_{2}\right)$, reactions with lone pair donors $\left(\mathrm{Me}_{2} \mathrm{CO}\right)$ and a radical addition (NO). The less efficient group comprises reactions with lone pairs $\left(\mathrm{N}_{2} \mathrm{O}, \mathrm{CO}_{2}\right.$ and $\left.\mathrm{HCl}\right)$ and the present study with $\mathrm{O}_{2}$ which may be regarded as a radical (or biradical) addition. The underlying feature which distinguishes between these groups appears to be a secondary barrier to reaction. The

Table 8 Lennard-Jones collision efficiencies at $298 \mathrm{~K}$ for selected reactions of $\mathrm{SiH}_{2}$

\begin{tabular}{|c|c|c|c|}
\hline Reaction partner & $k^{a}$ & $Z_{\mathrm{LJ}}^{a, b}$ & Efficiency $(\%)$ \\
\hline $\mathrm{SiH}_{4}$ & $4.60^{c}$ & 4.60 & 100 \\
\hline $\mathrm{GeH}_{4}$ & $3.06^{d}$ & 4.14 & 74 \\
\hline $\mathrm{C}_{2} \mathrm{H}_{4}$ & $3.5^{e}$ & 4.92 & 71 \\
\hline $\mathrm{C}_{2} \mathrm{H}_{2}$ & $4.0^{f}$ & 4.90 & 82 \\
\hline $\mathrm{NO}$ & 4.6 & 3.68 & $\geq 100$ \\
\hline $\mathrm{Me}_{2} \mathrm{CO}$ & $4.2^{g}$ & 5.54 & 76 \\
\hline $\mathrm{N}_{2} \mathrm{O}$ & $0.019^{h}$ & 4.12 & 0.46 \\
\hline $\mathrm{CO}_{2}$ & $<4.2 \times 10^{-5 i}$ & 4.10 & $<1.02 \times 10^{-3}$ \\
\hline $\mathrm{HCl}$ & $0.0723^{j}$ & 4.04 & 1.79 \\
\hline $\mathrm{O}_{2}$ & $0.164^{k}$ & 3.55 & 4.6 \\
\hline
\end{tabular}

${ }^{a}$ High pressure limiting values, units: $10^{-10} \mathrm{~cm}^{3}$ molecule ${ }^{-1} \mathrm{~s}^{-1} \cdot{ }^{b}$ The procedure for calculating $Z_{\mathrm{LJ}}$ is described in ref. 46. Parameters were taken from refs. 50, 51 and 52. ${ }^{c}$ Ref. 25. ${ }^{d}$ Ref. 50. ${ }^{e}$ Ref. 43. ${ }^{f}$ Ref. 44. ${ }^{g}$ Ref. 45. ${ }^{h}$ Ref. 6. ${ }^{i}$ Ref. 5. ${ }^{j}$ Ref. 10. ${ }^{k}$ This work. majority of $\mathrm{SiH}_{2}$ reaction systems studied involve the formation of an intermediate (donor-acceptor) complex, and if the barrier to its rearrangement is high enough then the second step is rate determining. This is the case for $\mathrm{SiH}_{2}+\mathrm{CO}_{2}{ }^{5}$ (the only significantly positive barrier measured up to now) and for $\mathrm{SiH}_{2}+\mathrm{HCl}^{10}$ where the barrier, although negative, causes an entropy bottleneck. This is also probably the case for $\mathrm{SiH}_{2}+$ $\mathrm{N}_{2} \mathrm{O}$, ${ }^{6}$ where rearrangement of the $\mathrm{H}_{2} \mathrm{SiNNO}$ initial adduct is likely to be rate determining (but calculations to prove this have not been carried out). In some of the reaction systems in Tables 7 and 8 there are also inefficiencies arising from third body assisted association effects which give rise to pressure dependences, but these have been taken into account by extrapolation to limiting high pressures to obtain the true bimolecular process rate constants reported in the tables. For the reactions of $\mathrm{SiH}_{2}$ with $\mathrm{CO}^{4}$ and $\mathrm{H}_{2} \mathrm{O}{ }^{7-9}$ (not listed), extrapolations of the pressure dependent rate constants are too long to give reliable bimolecular rate constants, but RRKM modelling still suggests that the values will be close to $100 \%$ of the collision numbers. For $\mathrm{SiH}_{2}+\mathrm{O}_{2}$, there is neither an obvious secondary barrier (see below) nor a significant pressure dependence to explain the only $c a$. 1 in 20 collision efficiency. The only obvious cause of a possible bottleneck here is the involvement of a spin forbidden process. This is discussed in the next section.

\section{Ab initio calculations}

The $a b$ initio calculations reported here are both more extensive and more detailed than carried out previously. Nevertheless they are generally in good agreement for those species and those parts of the PES where comparisons are possible. For the initial $\mathrm{H}_{2} \mathrm{SiOO}$ adduct we find the singlet state to be $14 \mathrm{~kJ}$ $\mathrm{mol}^{-1}$ (G3 level) and $26 \mathrm{~kJ} \mathrm{~mol}^{-1}$ (MRMP2/MCSCF $(8,8)$ level) more stable than the triplet, compared with the original value of $24 \mathrm{~kJ} \mathrm{~mol}^{-1}$ obtained by Nagase et al. ${ }^{17 b}$ (MP4//MP2/ 6-31G(d) level). For rearrangement of $\mathrm{H}_{2} \mathrm{SiOO}(\mathrm{S})$ to cyclo$\mathrm{H}_{2} \mathrm{SiO}_{2}$ our barrier of $19 \mathrm{~kJ} \mathrm{~mol}^{-1}$ compares favourably with values of $8-25 \mathrm{~kJ} \mathrm{~mol}^{-1}$ obtained by Nagase et al. ${ }^{17 b}$ (MP4 and GVB calculations). All previous calculations agree with ours that $\mathrm{Si}(\mathrm{OH})_{2}$ is the most stable species of the $\mathrm{SiH}_{2} \mathrm{O}_{2}$ family. Our results (G3) are compared, in Table 9, with those of previous work for species (including transition states) which have been studied by others. For convenience $\mathrm{Si}(\mathrm{OH})_{2}$ is used as the reference. The agreement is gratifyingly good although it is perhaps not too surprising that the results of $\mathrm{G} 3$ calculations should be close to those of $\mathrm{G} 2 .^{20}$ For our investigation of the lowest energy pathway from cyclo- $\mathrm{H}_{2} \mathrm{SiO}_{2}$ to $\mathrm{HSi}(=\mathrm{O}) \mathrm{OH}$, necessitating the CASSCF(6) calculations, the only comparison is with the calculations of Murakama et al. ${ }^{23}$ who reported a single transition state with a barrier of $27 \mathrm{~kJ} \mathrm{~mol}^{-1}$. Our calculations indicate clearly the two step nature of this process, with the higher energy $\mathrm{O}-\mathrm{O}$ bond breaking step (transition state TS3a) in the range $60-77 \mathrm{~kJ} \mathrm{~mol}^{-1}$ at the MRMP2 level (Table 4).

Examination of Fig. 3 shows this quite complex set of pathways is strongly exothermic involving secondary barriers significantly below the system energy threshold. Once the reaction is through the $\mathrm{H}_{2} \mathrm{SiOO}$ intersystem crossing $(\mathrm{T} \rightarrow \mathrm{S}$ ) step, the highest secondary barrier is that of TS2 $\left(102 \mathrm{~kJ} \mathrm{~mol}^{-1}\right.$ below threshold). From this point the lowest energy pathway proceeds via cyclo- $\mathrm{H}_{2} \mathrm{SiO}_{2}, \mathrm{H}_{2} \mathrm{Si}\left(\mathrm{O}^{*}\right)_{2}, \quad \mathrm{HSi}(=\mathrm{O}) \mathrm{OH}$ and $\mathrm{Si}(\mathrm{OH})_{2}$ with secondary barriers TS3a, TS4a, and TS6a which are even further below threshold. Even the final barriers to products, TS6b, TS6c, TS7a and TS7b are well below the threshold. Although in principle it is possible to calculate the lifetimes of all intermediate species on this surface, there appears to be so little resistance to reaction that we feel this is not necessary. Collisional stabilisation of intermediates cyclo- $\mathrm{H}_{2} \mathrm{SiO}_{2}, \mathrm{HSi}(=\mathrm{O}) \mathrm{OH}, \mathrm{Si}(\mathrm{OH})_{2}$ (and others) looks to 
Table 9 Comparison of ab initio calculated energies $\left(\mathrm{kJ} \mathrm{mol}^{-1}\right)$ for $\mathrm{SiH}_{2} \mathrm{O}_{2}$ species

\begin{tabular}{|c|c|c|c|c|c|}
\hline Molecular species & This work & Darling and Schlegel $^{a}$ & Zakariah and Tsang ${ }^{b}$ & Allendorf et al. ${ }^{c}$ & Murakama et al. ${ }^{d}$ \\
\hline $\mathrm{H}_{2} \mathrm{SiOO}(\mathrm{S})$ & 648 & 641 & - & - & - \\
\hline Cyclo- $\mathrm{H}_{2} \mathrm{SiO}_{2}$ & 377 & 375 & - & - & - \\
\hline $\mathrm{HSiOOH}$ & 498 & 494 & - & - & - \\
\hline $\mathrm{HSi}(=\mathrm{O}) \mathrm{OH}$ & 31 & 30 & 21 & - & 27 \\
\hline $\mathrm{Si}(\mathrm{OH})_{2}$ & 0 & 0 & 0 & 0 & 0 \\
\hline $\mathrm{H}_{2} \mathrm{O}+\mathrm{SiO}$ & 159 & 157 & 150 & - & 141 \\
\hline $\mathrm{H}_{2}+\mathrm{SiO}_{2}$ & 216 & 216 & 204 & 201 & - \\
\hline TS6a & 247 & - & 235 & - & 243 \\
\hline TS6b & 288 & - & 263 & - & - \\
\hline TS6c & 316 & - & 301 & - & 310 \\
\hline TS7a & 167 & - & 156 & - & 166 \\
\hline
\end{tabular}

be extremely unlikely. The end products identified here are all energetically accessible and their relative yields will depend on the microcanonical rate constants for their formation processes at the available energy. While it is beyond the scope of this study to calculate these, it seems likely that the pairs $\mathrm{H}_{2} \mathrm{O}+$ $\mathrm{SiO}$ and $\mathrm{H}_{2}+\mathrm{SiO}_{2}$ will be the most significant but that $\mathrm{H}$ atom formation is also reasonably likely. To our knowledge there are no end product studies with which to compare these predictions. Indirect evidence that $\mathrm{H}$-atoms are formed comes from the $\mathrm{SiH}_{4}-\mathrm{O}_{2}$ oxidation reaction ${ }^{12}$ where their formation can explain the occurrence of explosion at high temperatures via a branched chain reaction initiated by the familiar $\mathrm{H}+\mathrm{O}_{2}$ reaction.

\section{Intersystem crossing}

Intersystem crossing rate constants can vary enormously from $10^{12}$ to $10^{-2} \mathrm{~s}^{-1}$. 53 The value obtained here of $1.0 \times 10^{9} \mathrm{~s}^{-1}$ $\left(k_{1 \mathrm{~b}}\right)$ indicates a fairly fast process but with an efficiency which could still be only $c a$. $10^{-3}$, depending on what is considered a reasonable upper limit. Given that the transition probability calculated here for the lowest order crossing lies in the range $10^{-2}-10^{-4}$ this seems a reasonable result. Application of the theory of intramolecular radiationless transitions ${ }^{54}$ is beyond the scope of this study. The calculation of the rate constant (or lifetime) is, in any case complicated by the facts that $\mathrm{H}_{2} \mathrm{SiOO}$ is (i) a non-rigid molecule and (ii) formed with vibrational excess energy. To deal with the latter situation multidimensional vibronic couplings would need to be taken into account to assess the total probability of curve crossing. Thus while we cannot claim that our results prove that intersystem crossing is the rate determining step for the reaction of $\mathrm{SiH}_{2}+\mathrm{O}_{2}$, there is no obvious indication that this interpretation is wrong. It is also reasonable to suppose that the small pressure dependence of the overall rate constants (Table 2) could arise by collisional energy losses in $\mathrm{H}_{2} \mathrm{SiOO}(\mathrm{T})$, which would reduce its energy content and thereby alter the value of $k_{1 \mathrm{~b}}$. This could also account for the pressure dependence observed by CBEJ. ${ }^{13}$

\section{Other mechanistic comparisons}

In the analogous reaction of $\mathrm{CH}_{2}\left({ }^{1} \mathrm{~A}_{1}\right)$ with $\mathrm{O}_{2}$ it is interesting to note that the predominant pathway is collisionally induced intersystem crossing of $\mathrm{CH}_{2}\left({ }^{1} \mathrm{~A}_{1}\right)$ to $\mathrm{CH}_{2}\left({ }^{3} \mathrm{~B}_{1}\right)$ and not a chemical reaction ${ }^{15}$. The rate constant, which lies in the range $2.7-7.4 \times 10^{-11} \mathrm{~cm}^{3}$ molecule ${ }^{-1} \mathrm{~s}^{-1}, 15$ is quite high, suggesting probable formation of the bound collision adduct, $\mathrm{H}_{2} \mathrm{COO}(\mathrm{T})$. If this species redissociated rather than reacted further (because intersystem crossing to $\mathrm{H}_{2} \mathrm{COO}(\mathrm{S})$ is slow) then this situation would parallel our interpretation of the mechanism presented here for $\mathrm{SiH}_{2}+\mathrm{O}_{2}$. The only difference is that $\mathrm{H}_{2} \mathrm{SiOO}(\mathrm{T})$ cannot redissociate to form $\mathrm{SiH}_{2}\left({ }^{3} \mathrm{~B}_{1}\right)$ because, unlike methylene, silylene does not possess a lower-lying triplet state.
In an earlier study of $\mathrm{SiCl}_{2}$ with $\mathrm{O}_{2},{ }^{16}$ we have calculated parts of the analogous PES to that for $\mathrm{SiH}_{2}+\mathrm{O}_{2}$. The main similarity is the importance of cyclo- $\mathrm{Cl}_{2} \mathrm{SiO}_{2}$ as a crucial intermediate. However the further reactions of cyclo- $\mathrm{Cl}_{2} \mathrm{SiO}_{2}$ differ significantly from those of cyclo- $\mathrm{H}_{2} \mathrm{SiO}_{2}$ because of the much reduced likelihood of $\mathrm{Cl}$-atom migration compared to $\mathrm{H}$ atom migration (arising from the weakness of $\mathrm{O}-\mathrm{Cl}$ bonds compared with $\mathrm{O}-\mathrm{H}$ bonds). Nevertheless it is known that $\mathrm{Cl}_{2}$ is a product under the right conditions, probably arising from a Cl-atom initiated chain reaction involving the dissociation process:

$$
\text { cyclo- } \mathrm{Cl}_{2} \mathrm{Si}(\mathrm{O})_{2} \rightarrow \mathrm{Cl}+\mathrm{ClSi}(=\mathrm{O}) \mathrm{O} \text {. }
$$

\section{Acknowledgements}

We thank Dow-Corning Corporation for financial support of this work. R. B. also thanks the Spanish DGI for support under project BQU2002-03381. M. S. G. and I. A. thank the US Air Force Office of Scientific Research for support.

\section{References}

1 J. M. Jasinski, R. Becerra and R. Walsh, Chem. Rev., 1995, 95, 1203.

2 R. Becerra and R. Walsh, in Research in Chemical Kinetics, ed. R. G. Compton and G. M. Hancock, Elsevier, Amsterdam, 1995, vol. 3 , p. 263.

3 P. P. Gaspar and R. West, in The Chemistry of Organosilicon Compounds, ed. Z. Rappoport and Y. Apeloig, Wiley, Chichester, UK, 1998, vol. 2, ch. 43, p. 2463.

4 R. Becerra, J. P. Cannady and R. Walsh, J. Phys. Chem. A, 2001, 105, 1897.

5 R. Becerra, J. P. Cannady and R. Walsh, J. Phys. Chem. A, 2002, 106, 4922.

6 R. Becerra, H. M. Frey, B. P. Mason and R. Walsh, Chem. Phys. Lett., 1991, 185, 415.

7 U. N. Alexander, K. D. King and W. D. Lawrance, J. Phys. Chem. $A, 2002$, 106, 973.

8 R. Becerra, J. P. Cannady and R. Walsh, J. Phys. Chem. A, 2003, 107, 11049.

9 R. Becerra, N. Goldberg, J. P. Cannady, M. J. Almond, J. S. Ogden and R. Walsh, J. Am. Chem. Soc., 2004, 126, 6816.

10 R. Becerra, J. P. Cannady and R. Walsh, J. Phys. Chem. A, 2004, 108, 3987.

11 R. Becerra, S.-J. Bowes, J. S. Ogden, J. P. Cannady, M. J. Almond and R. Walsh, J. Phys. Chem. A, 2005, 109, 1071.

12 J. R. Hartman, J. Famil-Ghiriha, M. A. Ring and H. E. O'Neal, Combust. Flame, 1987, 68, 43.

13 J. O. Chu, D. B. Beach, R. D. Estes and J. M. Jasinski, Chem. Phys. Lett., 1988, 143, 135.

14 Y. Guo, M. Fikri, G. Friedrichs and F. Temps, Phys. Chem. Chem. Phys., 2003, 5, 4622.

15 G. Hancock and V. Haverd, Chem. Phys. Lett., 2003, 372, 288, and references cited therein.

16 N. Goldberg, J. S. Ogden, M. J. Almond, R. Walsh, J. P. Cannady, R. Becerra and J. A. Lee, Phys. Chem. Chem. Phys., 2003, 5, 5371 . 
17 (a) T. Akasaka, S. Nagase, A. Yabe and W. Ando, J. Am. Chem. Soc., 1988, 110, 6270; (b) S. Nagase, T. Kudo, T. Akasaka and W. Ando, Chem. Phys. Lett., 1989, 163, 23.

18 A. Patyk, W. Sander, J. Gauss and D. Cremer, Angew. Chem., Int. Ed., 1989, 28, 898.

19 G. Inoue and M. Suzuki, Chem. Phys. Lett., 1985, 122, 361.

20 C. L. Darling and H. B. Schlegel, J. Phys. Chem., 1993, 97, 8207.

21 M. R. Zakariah and W. Tsang, J. Phys. Chem., 1995, 99, 5308.

22 M. D. Allendorf, C. F. Melius, P. Ho and M. R. Zakariah, J. Phys. Chem., 1995, 99, 15285.

23 Y. Murakami, M. Koshi, H. Matsui, K. Kamiya and H. Umeyama, J. Phys. Chem., 1996, 100, 17501.

24 J. E. Baggott, H. M. Frey, K. D. King, P. D. Lightfoot, R. Walsh and I. M. Watts, J. Phys. Chem., 1988, 92, 4025.

25 R. Becerra, H. M. Frey, B. P. Mason, R. Walsh and M. S. Gordon, J. Chem. Soc., Faraday Trans., 1995, 91, 2723.

26 J. M. Jasinski and J. O. Chu, J. Chem. Phys., 1988, 88, 1678.

27 M. J. Frisch, G. W. Trucks, H. B. Schlegel, G. E. Scuseria, M. A Robb, J. R. Cheeseman, V. G. Zakrzewski, J. A. Montgomery, Jr, R. E. Stratmann, J. C. Burant, S. Dapprich, J. M. Millam, A. D Daniels, K. N. Kudin, M. C. Strain, O. Farkas, J. Tomasi, V. Barone, M. Cossi, R. Cammi, B. Mennucci, C. Pomelli, C. Adamo, S. Clifford, J. Ochterski, G. A. Petersson, P. Y. Ayala, Q. Cui, K. Morokuma, D. K. Malick, A. D. Rabuck, K. Raghavachari, J. B. Foresman, J. Cioslowski, J. V. Ortiz, A. G. Baboul, B. B. Stefanov, G. Liu, A. Liashenko, P. Piskorz, I. Komaromi, R. Gomperts, R. L. Martin, D. J. Fox, T. Keith, M. A. Al-Laham, C. Y. Peng, A. Nanayakkara, C. Gonzalez, M. Challacombe, P. M W. Gill, B. G. Johnson, W. Chen, M. W. Wong, J. L. Andres, M Head-Gordon, E. S. Replogle and J. A. Pople, GAUSSIAN 98 (Revision A9), Gaussian, Inc., Pittsburgh, PA, 1998.

28 L. A. Curtiss, K. Raghavachari, P. C. Redfern, V. Rassolov and J. A. Pople, J. Chem. Phys., 1998, 109, 7764.

29 (a) C. Gonzales and H. B. Schlegel, J. Chem. Phys., 1989, 90, 2154 (b) C. Gonzales and H. B. Schlegel, J. Phys. Chem., 1990, 94, 5523.

30 J. A. Pople, A. P. Scott, M. W. Wong and L. Radom, Israel J. Chem., 1993, 33, 345.

31 M. W. Schmidt, K. K. Baldridge, J. A. Boatz, S. T. Elbert, M. S. Gordon, J. H. Jensen, S. Koseki, N. Matsunaga, K. A. Nguyen, S. Su, T. L. Windus, M. Dupuis and J. A. Montgomery, Jr., J. Comput. Chem., 1993, 14, 1347.

32 M. W. Schmidt and M. S. Gordon, Annu. Rev. Phys. Chem., 1998, 49, 233.
33 B. O. Roos, P. R. Taylor and P. E. M. Siegbahn, Chem. Phys., 1980, 48, 157.

34 K. Ruedenberg, M. W. Schmidt, M. M. Gilbert and S. T. Elbert, Chem. Phys., 1982, 71, 41, 51, 65.

35 (a) W. J. Hehre, R. Ditchfield and J. A. Pople, J. Chem. Phys., 1972, 56, 2257; (b) M. M. Francl, W. J. Petro, W. J. Hehre, J. S. Binkley, M. S. Gordon, D. J. DeFrees and J. A. Pople, J. Chem. Phys., 1982, 77, 3654.

36 H. Nakano, J. Chem. Phys., 1993, 99, 7983.

37 K. Hirao, Chem. Phys. Lett., 1992, 190, 374.

38 (a) T. H. Dunning, Jr., J. Chem. Phys., 1989, 90, 1007; (b) D. E. Woon and T. H. Dunning, Jr., J. Chem. Phys., 1993, 98, 1358

39 H. A. Bethe and E. E. Salpeter, Quantum Mechanics of the One and Two Electron Atoms, Plenum, New York, 1977.

40 See, for example, R. P. Wayne, Chemistry of Atmospheres, Oxford University Press, 3rd edn., 2000, ch. 5, pp. 346-347.

41 (a) M. T. Reetz, Angew. Chem., Int. Ed. Engl., 1972, 11, 129; (b) M. T. Reetz, Angew. Chem., Int. Ed. Engl., 1972, 11, 130.

42 A. G. Brook and A. R. Bassindale, in Rearrangements in Ground and Excited States, ed. P. de Mayo, Academic Press, 1982, vol. 2, p. 149.

43 N. Al-Rubaiey and R. Walsh, J. Phys. Chem. A, 1994, 98, 5303.

44 R. Becerra and R. Walsh, Int. J. Chem. Kinet., 1994, 26, 45.

45 R. Becerra, J. P. Cannady and R. Walsh, J. Phys. Chem. A, 1999, 103, 4457.

46 N. Matsunaga, S. Koseki and M. S. Gordon, J. Chem. Phys., 1996, 104, 7988.

47 C. D. Eley, M. C. A. Rowe and R. Walsh, Chem. Phys. Lett., 1986, 126, 153.

48 V. Sandhu, A. Jodhan, J. Safarik, O. P. Strausz and T. N. Bell, Chem. Phys. Lett., 1987, 135, 260.

49 J. Safarik, V. Sandhu, E. M. Lown, O. P. Strausz and T. N. Bell, Res. Chem. Int., 1990, 14, 105.

50 R. Becerra, S. Boganov and R. Walsh, J. Chem. Soc., Faraday Trans., 1998, 94, 3569.

51 R. Becerra and R. Walsh, J. Organomet. Chem., 1991, 408, 149.

52 R. C. Reid, J. M. Prausnitz and B. E. Poling, The Properties of Gases and Liquids, McGraw-Hill, New York, 4th edn., 1988.

53 N. J. Turro, Modern Molecular Photochemistry, Benjamin/Cummings, Menlo Park, CA, 1978.

54 M. Bixon and J. Jortner, J. Chem. Phys., 1968, 48, 715. 